\title{
PATTERNS AND PROCESSES OF GROUNDWATER INVASION BY COPEPODS IN THE INTERIOR LOW PLATEAUS OF THE UNITED STATES
}

\author{
VZORCI IN PROCESI NASELJEVANJA CEPONOŽCEV V \\ PODZEMELJSKE VODE NA PLANOTI INTERIOR LOW PLATEAUS \\ V ZDRUŽENIH DRŽAVAH
}

\author{
Julian J. LEWIS ${ }^{1} \&$ Janet W. REID ${ }^{2}$
}

\begin{abstract}
UDC 574.9:595.34 (7)

Julian J. Lewis \& Janet W. Reid: Patterns and Processes of Groundwater Invasion by Copepods in the Interior Low Plateaus of the United States

The copepod crustacean fauna collected from subterranean habitats, including caves, wells, and the hyporheos of streams in and near the Interior Low Plateaus of the United States is dominated by Cyclopoida, with 39 species, followed by Harpacticoida with 9, and Calanoida with 2. Nearly all of the harpacticoid and calanoid species are widespread, primarily surfacedwelling generalists. Fourteen of the cyclopoids, members of the genera Diacyclops, Itocyclops, Megacyclops, and Rheocyclops, are apparently obligate stygobionts or hyporheic. Several of the species that are more strongly modified for subterranean existence occur only in the more southern, unglaciated areas. Our sampling data support the hypothesis that the more specialized, groundwater-interstitial species have been unable to disperse into previously glaciated regions; whereas some, less-specialized species may have invaded groundwaters from surface habitats as the glaciers receded.
\end{abstract}

Key words: Copepoda, Crustacea, biogeography, glaciation, North America.
Izvleček UDK 574.9:595.34 (7)

Julian J. Lewis \& Janet W. Reid: Vzorci in procesi naseljevanja ceponožcev $v$ podzemeljske vode na planoti Interior Low Plateaus $v$ Združenih državah

Med ceponožnimi raki, vzorčevanimi v podzemeljskih habitatih, $\mathrm{v}$ jamah, vrtinah in rečnem hiporejiku blizu ter na sami planoti Interior Low Plateaus (ZDA), prevladujejo ciklopoidi z 39 vrstami, sledijo jim harpaktikoidi z devetimi vrstami in kalanoidi z dvema vrstama. Skoraj vse identificirane harpaktikoidne in kalanoidne vrste so splošno razširjene, površinski generalisti. Štirinajst ciklopoidnih vrst, predstavnikov rodov Diacyclops, Itocyclops, Megacyclops in Rheocyclops, je stigobiontov ali prebivalcev hiporejika. Vrste, ki imajo močneje izražene prilagoditve na podzemeljsko življenje, najdemo $\mathrm{v}$ južnih predelih, ki v času ledenih dob niso bili pokriti z ledenim pokrovom. Rezultati vzorčenja podpirajo hipotezo, da tiste vrste, ki so bolj specializirane na podzemeljske-intersticialne pogoje niso bile sposobne razširjenja $\mathrm{v}$ predhodno poledenele predele; medtem ko so nekatere, manj specializirane vrste ob umikanju ledenikov uspele prodreti iz površinskih v podzemeljske vode. Ključne besede: Copepoda, Crustacea, biogeografija, poledenitev, Severna Amerika.

\section{INTRODUCTION}

We review published information and present new geographical records for the copepod crustaceans collected from subterranean habitats in and near the Interior Low Plateaus (ILP) physiographic province of the United States. Fenneman (1938) described the ILP as an area of relative lowlands between the Appalachians to the east and the Ozark Plateaus to the west. The ILP stretches from northern Alabama, northward through Tennessee and Kentucky into southern Indiana and Illinois. Much of this area is karst topography and contains thousands

\footnotetext{
${ }^{1}$ Lewis \& Associates LLC, Cave, Karst \& Groundwater Biological Consulting, 17903 State Road 60, Borden, IN 47106-8608, U.S.A.; e-mail lewisbioconsult@aol.com

2 JWR Associates, 1100 Cherokee Court, Martinsville, VA 24112-5318, and Research Associate, Virginia Museum of Natural History, U.S.A.; e-mail: jwrassociates@sitestar.net
}

Received/Prejeto: 07.02.2007 
of known caves. The northern boundary of the ILP is the terminus of the Illinoian glaciation. Herein we trace the present-day distribution of the copepod species in this region, and attempt to infer the historical patterns and routes of their re-entry into previously glaciated areas.

The Interior Low Plateau region has been the focus of many earlier studies relating to the fauna of caves and karst, because of the notoriety of some local sites, especially in the central Kentucky karst, including what is now Mammoth Cave National Park. In 1928, C. Bolívar and René Jeannel made collections of copepods from numerous caves in the eastern United States, resulting in the first descriptions (Chappuis 1929, 1931) of subterranean copepod taxa from this country: Megacyclops donnaldsoni (Donnaldson Cave, Lawrence County, Indiana), Diacyclops jeanneli (Marengo Cave, Crawford County, Indiana), and Bryocamptus morrisoni (Horse Cave, Hart County, Kentucky; and Donnaldson Cave). Cyclops clandestinus (renamed Diacyclops yeatmani by Reid, 1988) was described from Big Mouth Cave, Grundy County, Tennessee and a drain tile in Vermilion County, Illinois by Yeatman (1964). Barr (1967) summarized collections of 17 taxa reported from Mammoth Cave and other caves in the central Kentucky karst by his own field work, as well as that of Kofoid (1899) and Chappuis (1931).

Lewis began sampling cave faunas in the eastern United States in the 1970s, but only started focusing attention on the micro-crustacean fauna in the 1990s (Lewis, and Lewis et al. 1998-2006). The initial impetus for these collections was the desire to rediscover Diacyclops jeanneli in Marengo Cave and the surrounding area during a survey conducted for The Nature Conservancy in Indiana. The results from this sampling made it clear that a significant assemblage of subterranean microcrustaceans was present in the groundwaters of the midwestern United States. Presented herein are the results of Lewis' approximately 15 years of sampling. Newly described copepod taxa resulting from these collections are Rheocyclops indiana (Reid et al. 1999), Diacyclops salisae, D. lewisi, D. indianensis and D. conversus (Reid 2004), and a new species of Itocyclops (Reid in review).

\section{SAMPLING METHODS}

A variety of means were used to collect copepods from different windows into the groundwater. Plankton drift samples were collected by hanging a plankton net over the orifice of a spring, in a flowing cave stream, or at the mouth of a drain tile. In deeper streams, rimstone pools, or drip pools in caves, the net was drawn through the water. In shallow drip pools, fed by the epikarst, water was dipped with a cup and strained through the plankton net. In cave streams with sufficiently deep gravel, the Karaman-Chappuis technique was used to gather fauna living in the interstices. In wells, copepods and other fauna came readily to jars equipped with perforated lids and baited with a single, uncooked dead shrimp; these were left overnight and then retrieved. Longer trapping intervals appeared to result in fouling of the water and decrease in the fauna that was captured. Finally, a BouRouch pumpwell was used to sample hyporheic interstices of the Blue River in southern Indiana.

All samples were transported alive to the laboratory for visual inspection. The copepods and other fauna were much easier to detect alive than preserved. The animals were removed from the sample with an eye dropper, and then preserved in $70 \%$ ethanol. Voucher specimens were deposited in the collections of the National Museum of Natural History (Smithsonian Institution), or the Virginia Museum of Natural History.

\section{PATTERNS OF DISTRIBUTION AND HABITAT}

Like any other puzzle, a modicum of the pieces have to be gathered and arranged before even a hint of the overall picture begins to emerge. Enough sampling from caves and other windows into groundwater in the Interior Low Plateaus of the east-central United States has now been conducted to permit a few observations about the patterns of distribution, as well as to infer the processes by which copepods have invaded this realm.
One of the ecological fortes of cyclopoid copepods of the genus Diacyclops is their use of groundwater habitats, and it appears that some species are indeed stygobionts. The best-known of these in the United States is Diacyclops jeanneli. For many decades after its discovery in 1928 , this species remained obscure, with even its microhabitat in Marengo Cave uncertain. Using shrimp-baited jar traps, Lewis (1996) found D. jeanneli in a well, not 
associated with caves or karst, on the edge of the Knobstone Escarpment, in Floyd County, Indiana. This well had been hand-dug many decades earlier, penetrating alluvium and then the top of the New Albany Shale to a total depth of 21 feet $(6.4 \mathrm{~m})$ below the surface. Also found in the well was the phreatobitic isopod Caecidotea teresae, previously known from a series of drain tiles across the street on the Indiana University Southeast campus in New Albany, associated with an undescribed groundwater amphipod Stygobromus sp. (Lewis 1982).

At the time that $D$. jeanneli was first collected from Marengo Cave, a relatively small amount of passage had been explored, and none of the known passages contained a significant stream. Since that time, not only one, but two, cave "rivers" have been connected by explorers to the historic section of Marengo Cave. Lewis (1998) took plankton drift samples in these streams, but did not find $D$. jeanneli. Further sampling revealed that these copepods are fairly common in drip pools in the upper level of the cave, even in shallow pools on the concrete trails used by tourists visiting the cave. The area of the cave where $D$. jeanneli was found is highly decorated with stalactites, stalagmites, and rimstone pools. In contrast to the lower-level cave rivers, all of the water in this part of the cave is epikarstic in origin.

Subsequently, D. jeanneli was found in five other southern Indiana caves, in pools fed by ceiling drips. In several instances, the stygobiont ostracod Pseudocandona jeanneli or a related, undescribed species of Pseudocandona were taken from the same samples. Most recently, $D$. jeanneli has been taken from a seep emerging from alluvium in Clark County, Indiana. It appears that D. jeanneli is an inhabitant of groundwater interstices, whether in a cave or not. The cave records may well be incidental findings, where the copepods have fallen in drip water from the preferred epikarst habitat. Clearly, this species is at home in non-karst groundwater interstices as well. Based on the collection of fresh material as noted, Reid (2004) redescribed the species and summarized the localities from which it is now known.

In contrast, present data suggest that Megacyclops donnaldsoni is a strict cavernicole. Now known from sporadically located collections in Indiana, Kentucky, and Tennessee, all records are from caves, and all but one from a cave river. Reid (unpublished data) identified a single female ascribable to $M$. donnaldsoni, collected from a stream in Cemetery Pit Cave in Dade County in northwest Georgia, January 2001, by J. Jensen and W. Reeves (specimen in $\mathrm{VMNH}$ ). The single non-stream habitat was a deep rimstone pool, probably near local base-level, in Dry Cave, Grundy County, Tennessee. Bunting (1973) did not mention the subhabitat of his record from a cave in Tennessee.
Diacyclops yeatmani has now been recorded from the hyporheos of the Blue River in southern Indiana, a drain tile in glaciated Illinois, and three caves in Tennessee. This is remarkable because the species is distributed both south of the Illinoian glacial maximum, and a significant distance north of it, in the till plains of Illinois. A somewhat similar distribution pattern is known for $D$. indianensis, which is recorded from the type-locality in a cave in glaciated southeastern Indiana, and from seven caves in Tennessee. In Indiana $D$. indianensis occurs in a cave about $20 \mathrm{~km}$ outside the Illinoian glacial boundary region, whereas D. yeatmani occurs perhaps $80-100 \mathrm{~km}$ inside this boundary.

Several other species of Diacyclops are presently known from one or two sites in southern Indiana: $D$. lewisi, D. salisae, D. conversus. All display some degree of morphological adaptation to the groundwater environment, and are known only from groundwater habitats. Otherwise, little is known of the ecology of these species.

Of note, serial sampling over a three-year period produced four species of Diacyclops from the Bou-Rouch pumpwell placed in a gravel bar on the Blue River in southern Indiana. These were D. sororum in 1997, D. conversus and D. yeatmani in 1998, and D. nearcticus in 2000 (Lewis 1998, Reid 2004).

One of the typical habitats of D. nearcticus is the hyporheos of streams (Strayer and Reid, 1999). In Indiana it has been found, using a Bou-Rouch pumpwell, inhabiting the hyporheic zone of the Blue River, as well as the interstices of stream gravel in Bond Cave, in Orange County. This species has been otherwise found over a broad range in the eastern United States, encompassing an area from Massachusetts to the Great Lakes and south to Florida. The distribution is sporadic and it has never been found in abundance at any site. In Florida, it is found in the Everglades karst in seasonally dry solution holes (Bruno et al. 2000).

Another very widespread species is $D$. chrisae, which in Indiana was found in White County just north of the Wisconsinan glacial maximum. It was previously known only from interstitial sediments in eastern Maryland and Ontario (Reid 1992).

Second to Diacyclops, cyclopoids of the genus Acanthocyclops were the most frequently recorded copepod inhabitants of groundwaters. Acanthocyclops robustus is generally considered a species of surface waters, but inspection of Appendix 1 shows it to be the most frequently collected of any of the copepods encountered. Some of the collection sites are remote from any point of surface input. This "surface" species is apparently very comfortable in groundwaters. A total of seven species of Acanthocyclops were recorded, suggesting that the group as a 
whole has more than a passing relationship to groundwater habitats. For example, the rare but widespread species Acanthocyclops parasensitivus was found in a seep in Indiana, where it emerges from saturated interstices of gravel, and from drip pools of epikarstic origin in a cave in Tennessee. Several of the species of Acanthocyclops are apparently stygophilic or perhaps phreatophilic.

Appendix 1 includes a number of species that are, without a doubt, common fauna of surface habitats. Some, such as Acanthocyclops brevispinosus, Acanthocyclops einslei, Eucyclops agilis, and Eucyclops conrowae, are reported herein primarily from springs, rather than windows into deeper groundwaters. These collections represent copepods that are visitors to groundwater, but may find the cool, environmentally stable spring pools to be suitable habitat. The calanoid Skistodiaptomus pallidus may well be only an accidental traveler through groundwater conduits. The group consisting of Osphranticum labronectum, A. vernalis, M. albidus, and Orthocyclops modestus, found in a pool in Patton Cave, Tennessee, is typical of small, surface waterbodies, and may have entered through seepage from a nearby lake.

Contrary to what might have been expected for the strictly benthic harpacticoids, most of the species found are very widespread and common in surface habitats in North America. Members of the genera Attheyella, Bryocamptus, and Moraria are especially common in spring seeps and wet moss. The exception is Bryocamptus morrisoni s.str., which is known only from two cave-river collections in Indiana and Kentucky.
Finally, of the genera in our list, Rheocyclops and Itocyclops remain the most enigmatic. Rheocyclops indiana was first discovered in a drip pool in Ladder Cave, Washington County, Indiana, in the company of an undescribed species of the amphipod genus Stygobromus. This Rheocyclops was subsequently found in a drip pool in Elrod Cave, Orange County. The first impression was that this species was probably endemic to epikarstic habitats in the south-central karst belt of southern Indiana. This notion was eliminated with the discovery by Reid (unpublished data) of $R$. indiana from two hyporheic habitats in the Great Smoky Mountains National Park. These finds suggest that this species is relatively widespread, but rarely collected, probably because of its cryptic nature and small size.

Itocyclops yezoensis was formerly known from Japan and Alaska, when it was subsequently reported from Great Smoky Mountains National Park, in Sevier County, Tennessee (Reid and Ishida 2000); and recently from a streambank in Henry County, southern Virginia (Reid 2006). Although we were surprised at the range extension of Rheocyclops from Indiana to the Smoky Mountains, this distance pales in comparison to that of $I$. yezoensis. A second North American species of Itocyclops was recently discovered in caves that lie in the path of an interstate highway project in eastern Kentucky (Lewis and Lewis 2006a), and also in a cave in north-central Tennessee (present report). The third known species of the genus was found in a spring seep in western Virginia (Reid, in review).

\section{PROCESSES OF SUBTERRANEAN INVASION}

In Indiana, where our sampling has been most concentrated, the availability of aquatic habitats can be estimated by the glacial history of the state. The glacial history of Indiana (summarized here from IGS 2007) is quite complex and the record is incomplete, as successive ice sheets eroded the deposits of the previous glacial advances and created discontinuities in the geologic record. The present theory of glacial geologists is that the ice sheets initially progressed along valley systems during the Tertiary, in the area now comprising the boundary between the U.S. and Canada. As the glaciers moved southward, these valleys were carved into large basins that would become the present-day Great Lakes. The orientations of these basins in turn strongly influenced the direction and magnitude of glaciations in Indiana.

The climatic record derived from cores of extant glaciers in Greenland as well as ocean floor geochemical evidence suggest $12-18$ periods over the last two million years that were cold enough to form continental glaciers. In Indiana, there is evidence that at least 11 distinct glacial events occurred. These are divided into three major stages, each of which had several ice advances:

(1) pre-Illinoian Stage, which is the least understood because of erosion and burial of the deposits. It comprises the period between initial glaciation and the Illinoian (700,000 - 300,000 years before present [BP]). The first Pleistocene ice sheet to reach Indiana appears to have entered the state from directly to the north (now Michigan). The glacier, thought to have been between a half mile and a mile $(0.8-1.6 \mathrm{~km})$ thick at the leading edge, moved slowly as it encountered bedrock hills and valleys that slowed its progress. The Teays River valley, the major drainage conduit for the eastern U.S., was 200400 feet (60-120 m) deep prior to glaciation. After burying this large stream valley, the first glacier stopped about mid-state, then slowly receded to the north. 
(2) Illinoian Stage, of which deposits are today exposed on the surface in southeast and southwest Indiana, lasted from about 300,000 to 140,000 years BP. The southeastern Indiana karst was completely glaciated during this stage. The area comprising the south-central karst area remained ice-free, but the limestone band continues to the north where it is buried under the till plain. During the subsequent Sangamon interglacial, the flattened topography of the southeastern karst was dissected to some extent by streams down-cutting through the till. The modern-day Ohio River was formed and became a major drainage conduit for the water from the melting glaciers.

(3) Wisconsin Stage, from about 50,000 to 10,000 years ago. The northern half of Indiana is covered with deposits of this age. The caves in the southeastern Indiana karst region lie under Illinoian till, but almost all occur south of the Wisconsinan glacial boundary. The occurrence of enterable caves ends near where the limestone strata meet the edge of the Wisconsinan glacial boundary in Decatur County, although other caves may certainly exist buried under the carpet of till.

Thus, different areas of Indiana, including the two karst areas, have been free of glaciers for relatively well-established time periods. The south-central karst has been ice-free and suitable, at least in that respect, throughout the Pleistocene. The southern-most area of the southeastern karst, in Clark, Jefferson, Jennings, and Ripley counties, was available from the Sangamon onward. The sites sampled in Vermilion Co., Illinois and White Co., Indiana both lie on Wisconsinan -age till plains.

This brings us to a point of controversy in the theories concerning the zoogeography and evolution of subterranean crustaceans in glaciated North America. How did tiny, substrate-bound animals such as Diacyclops yeatmani, $D$. indianensis, $D$. salisae, $D$. lewisi, or the more heavily collected (because they are easily visible to the naked eye) amphipod Bactrurus mucronatus and isopod Caecidotea kendeighi get to their present-day ranges deep within the glaciated areas? Two hypotheses have been advanced to account for this distribution pattern (Holsinger 1978, 1981, 1986; Lewis 1983, Lewis and Bowman 1981, Koenemann \& Holsinger 2001): (1) survival under the ice; (2) dispersal from areas that remained ice-free after the retreat of the glaciers.

These authors have recognized that some combination of the two processes might well have occurred. We elaborate on a refinement of this idea. The continental glaciers were essentially rivers of slowly flowing ice, moving southward from their sources. It is thought that after the initial glaciation of Indiana, subsequent glaciers moved relatively quickly due to abundant water at the base of the glacier that served to lubricate the ice sliding over previously glaciated terrain. At the front edge of the glacier, the ice was constantly melting. During periods when melt rates were slow, the glaciers advanced, but receded when melting outpaced deposition of new ice.

Aquatic habitat for cold-stenothermic crustaceans should have been abundant. Peripheral to the glaciers, suitable habitat might have been available in three areas: (1) streams and meltwater lakes in front (south) of the glaciers; (2) the leading edge of the glacier where melting was occurring; (3) underneath the glacier, particularly in a zone behind the leading edge.

If the glaciers were in fact moving on a lubricating base of liquid water, if other factors were not limiting (e.g., dissolved oxygen, nutrients, scouring), then we see no reason to think that crustaceans would not have been present, particularly in the zone under the edge of the glacier. Beyond the glacier, meltwater lakes should have provided ideal habitats. This meltwater zone would have traveled northward with the receding glaciers, and the community present in it would have migrated northward as well. This would account for the presence of stygobiont species such as Diacyclops yeatmani and D. chrisae far north of the glacial maxima.

As the present interglacial proceeded, the disappearance of meltwater lakes in southern Indiana would have encouraged the invasion of the other, major aquatic habitat that remained available: groundwater. When lakes and streams draining from the receding glaciers dried, some of the cyclopoids followed the water into the interstices of the saturated glacial till. Evidence for this is the presence of Diacyclops salisae and D. lewisi in this habitat today. Robertson and Milner (2006) reported that Diacyclops spp. were the most characteristic members of the meiofauna in newly formed meltwater streams (ca. 50 years post recession of the glacier) in Glacier Bay National Park, Alaska.

Eleven species of Diacyclops have now been found during sampling of groundwater habitats in Indiana. Reid and Strayer (1994) reviewed the morphological modifications seen in subterranean copepods, some of which are noted in Table 1. Of the species of Diacyclops known from Indiana, D. crassicaudis brachycercus and $D$. navus exhibit slight or no morphological adaptations to subterranean life, and are most often found in epigean habitats. Diacyclops lewisi and D. salisae are also relatively unmodified, and occur in wells. Diacyclops nearcticus and D. sororum occur in both epigean situations and hyporheic sediments. Diacyclops chrisae, D. conversus, $D$. indianensis, and D. yeatmani have been found in deep interstitial and hyporheic situations. Diacyclops jeanneli occurs mainly in cave pools, but as suggested above may well be an inhabitant of the epikarst. Most of these lat- 
ter species exhibit at least some morphological modifications.

For subterranean cyclopoid copepods found in Indiana, Table 1 summarizes a comparison of morphological adaptation as a function of the length of time available for colonization of the region. Of the Diacyclops species, $D$. jeanneli and D. conversus are the most strongly modified for subterranean existence, and both occur only in the unglaciated area of south-central Indiana. Indeed, D. jeanneli has been found to the very edge of the limit of Illinoian glaciation on the sides of the Knobstone Escarpment in Clark and Floyd counties. Strayer and Reid (1999) analyzed the distribution of hyporheic cyclopoids in glaciated versus unglaciated areas in the eastern United States, and noted a break in species composition associated with the Pleistocene glacial maxima. They suggested that the more specialized interstitial species, such as Diacyclops jeanneli and members of Rheocyclops, have been unable to disperse into the glaciated regions. Our sampling data lend some additional evidence to this theory, although the correlation is clouded by the differences in microhabitat preferences among the species. Further evidence is provided by the near-absence of a specialized subterranean harpacticoid fauna in this region, where, apparently, mainly the most adaptable generalist species were able to reach the subterranean habitats.

Tab. 1. Species of Diacyclops, Megacyclops, and Rheocyclops known to inhabit different regions in Indiana, according to the length of time available since the last glaciation in that region, and the degree of morphological modification of each species. The degree of modification is estimated according to the number of several characters (total given in parentheses): oligomerization of the antennular segments, loss of one or more antennal basipodite setae, oligomerization of segments of the swimming legs, shortening of the terminal endopodite segment of the leg 4 endopodite, and the anal operculum posteriorly produced.

\begin{tabular}{lll}
\hline Time of last glaciation & Species & Relative degree of modification \\
\hline Unglaciated & Megacyclops donnaldsoni & Slight (1) \\
\hline & Diacyclops navus* & None \\
\hline & Diacyclops crassicaudis brachycercus* & Moderate (2) \\
\hline & Diacyclops nearcticus* & Moderate (2) \\
\hline & Diacyclops yeatmani & Moderate (2) \\
\hline & Diacyclops conversus & Moderate (3) \\
\hline $\begin{array}{ll}\text { Illinoian glaciation, ice-free } \\
\text { ca. 140,000 years BP }\end{array}$ & Diacyclops jeanneli & Moderate (3) \\
\hline & Rheocyclops indiana & Advanced (4) \\
\hline & Diacyclops lewisi & None \\
\hline $\begin{array}{l}\text { Wisconsinan glaciation, ice-free } \\
\text { ca. 10,000 years BP }\end{array}$ & Diacyclops chrisa* & None \\
\hline
\end{tabular}

* Also occurs in previously glaciated regions elsewhere in North America.

\section{ACKNOWLEDGEMENTS}

We are grateful to all of the collectors who helped gather material over the years, particularly Salisa L. Lewis, Ronnie Burns, Diane Tecic, Heather Garland, and Cory Holliday. JJL gratefully acknowledges the support of The Nature Conservancy, Indiana Natural Heritage Program (Indiana Department of Natural Resources), Hoosier National Forest (U.S.D.A. Forest Service), Big Oaks National Wildlife Refuge (U.S. Fish and Wildlife Service), and the Tennessee Wildlife Resources Agency, as well as funds from the environmental impact studies for federal interstate highway projects I-69 and I-66 administered by the Kentucky Transportation Cabinet and the Indiana Department of Transportation. JWR gratefully acknowledges the receipt of material support from the Virginia Museum of Natural History and the National Museum of Natural History (Smithsonian Institution). 


\section{REFERENCES}

Barr, T. C., Jr., 1967: Ecological studies in the Mammoth Cave System of Kentucky I: The biota.- International Journal of Speleology, 3, 147-204, Bologna.

Bruno, M. C., Reid, J. W. \& Perry, S. A., 2000: New records of copepods from Everglades National Park (Florida): descriptions of two new species of Elaphoidella (Harpacticoida, Canthocamptidae), and supplementary description of Diacyclops nearcticus Kiefer (Cyclopoida, Cyclopidae).- Crustaceana, 73, 1171-1204, Leiden.

Bunting, D. L., 1973: The Cladocera and Copepoda of Tennessee. II. Cyclopoid copepods.- Journal of the Tennessee Academy of Science, 48, 138-141, Murfreesboro.

Chappuis, P. A., 1929: Copépodes cavernicoles de l'Amérique du Nord (Note préliminaire).- Bulletin de la Société des Sciences de Cluj (Roumanie), 4, 51-57, Cluj.

Chappuis, P. A., 1931: Campagne spéologique de C. Bolivar et R. Jeannel dans l'Amérique du Nord (1928) Crustacés copépodes. Biospeleologica No. 56-4.Archives de Zoologie Expérimentale et Générale, 71, 345-360, Paris.

Fenneman, N. E., 1938: Physiography of the eastern United States. McGraw-Hill Book Company, New York, 714 pages.

Holsinger, J. R., 1978: Systematics of the subterranean amphipod genus Stygobromus (Crangonyctidae), part II: species of the eastern United States.- Smithsonian Contributions to Zoology, 266, 1-144, Washington.

Holsinger, J. R., 1981: Stygobromus Canadensis, a troglobitic amphipod crustacean from Castleguard Cave, with remarks on the concept of cave glacial refugia. -Proceedings of the $8^{\text {th }}$ International Congress of Speleology. Bowling Green, Kentucky, 1, 93-95.

Holsinger, J. R., 1986: Zoogeographic patterns of North American subterranean amphipod crustaceans. In Gore, R. H. \& K. L. Heck, editors. Crustacean Biogeography in Crustacean Issues. Balkema, Rotterdam, 85-106.

Indiana Geological Survey, 2007: A Landscape in Motion. Indiana Geological Survey. http://igs.indiana. edu/Geology/ancient/freezeframe/index.cfm

Kofoid, C.A., 1899: The plankton of Echo River, Mammoth Cave.- Transactions of the American Microscopical Society, 21, 113-126, Lawrence.

Koenemann, S. \& Holsinger, J. R., 2001: Systematics of the North American subterranean amphipod genus Bactrurus (Crangonyctidae).- Beaufortia, 51, 1-56.
Lewis, J. J., 1982: A diagnosis of the Hobbsi Group, with descriptions of Caecidotea teresae, n. sp., and C. macropropoda Chase and Blair (Crustacea: Isopoda: Asellidae).- Proceedings of the Biological Society of Washington, 95, 338-346, Lawrence.

Lewis, J. J., 1983: The obligatory subterranean invertebrates of glaciated southeastern Indiana.- National Speleological Society Bulletin, 45, 34-40, Huntsville.

Lewis, J. J., 1996: Inventory of the subterranean biota threatened by urbanization of Clark and Floyd Counties, Indiana. Final report, Non-game and Endangered Wildlife Program, Division of Fish and Wildlife, Indiana Department of Natural Resources, 71 pages.

Lewis, J. J., 1998: The subterranean fauna of the Blue River area. Final Report, The Nature Conservancy, Species at Risk Program (USGS), Indiana Natural Heritage Program and Indiana Non-game and Endangered Wildlife Program, 266 pages.

Lewis, J. J., 1999: The subterranean fauna of the Interior Low Plateaus. Final Report, The Nature Conservancy, 26 pages.

Lewis, J. J., 2001: A biological reconnaissance of the Rumbling Falls Cave System, Van Buren County, Tennessee. Final Report, Tennessee Environmental Council, National Speleological Society, World Wildlife Fund, 21 pages.

Lewis, J. J., 2002: Status and distribution surveys for rare cave-dependent organisms recently identified from the Rumbling Falls Cave System, Van Buren County, Tennessee. Final Report, U.S. Fish \& Wildlife Service, 48 pages.

Lewis, J. J., 2004: Interstate 66 karst faunal study. Environmental Impact Statement.

Lewis, J. J., 2005: Cave fauna of the I69 Corridor in Monroe County, Indiana. Environmental Impact Statement, Baker Engineering, Inc. and Ozark Underground Laboratory.

Lewis, J. J. \& Bowman, T. E., 1981: The subterranean asellids (Caecidotea) of Illinois (Crustacea: Isopoda: Asellidae).- Smithsonian Contributions to Zoology, 335, 1-66, Washington, D.C.

Lewis, J. J., Burns, R. \& Lewis, S., 2004: The subterranean fauna of the Hoosier National Forest. U.S. Department of Agriculture, Forest Service, 190 pages.

Lewis, J. J. \& Lewis, S. L., 2005: Bioinventory of the subterranean fauna of Tims Ford State Park, Franklin County, Tennessee. Tennessee Natural Heritage Program, 28 pages. 
Lewis, J. J. \& Lewis, S. L., 2006a: Cave Fauna in the Interstate 66 Somerset to London Corridor. In: Rea, G. T., editor, Proceedings of the 2005 National Cave \& Karst Management Symposium, Albany, New York, 15-20.

Lewis, J. J. \& Lewis, S. L., 2006b: Subterranean fauna of the Buddha Karst Preserve, Lawrence County, Indiana. Indiana Department of Natural Resources, Division of Nature Preserves, 19 pages.

Lewis, J. J. \& Rafail, S. T., 2002: The subterranean fauna of the Big Oaks National Wildlife Refuge. U.S. Department of the Interior, Fish \& Wildlife Service, Indiana Department of Natural Resources, Natural Heritage Program, 77 pages.

Lewis, J. J., Moss, P., Tecic, D. \& Nelson, M., 2002: A Conservation Focused Inventory of the subterranean invertebrates of the Southwestern Illinois Karst.- Journal of Cave and Karst Studies, 65, 9-21, Huntsville.

Reid, J. W., 1988: Copepoda (Crustacea) from a seasonally flooded marsh in Rock Creek Stream Valley Park, Maryland.- Proceedings of the Biological Society of Washington, 101, 31-38, Washington, D.C.

Reid, J. W., 1992: Redescription of Diacyclops nearcticus (Kiefer, 1934) and description of four similar new congeners from North America, with comments on D. crassicaudis (G.O. Sars, 1863) and D. crassicaudis var. brachycercus (Kiefer, 1927)(Crustacea: Copepoda).- Canadian Journal of Zoology, 70, 1445-1469, Ottawa.

Reid, J. W., 2004: New records and new species of the genus Diacyclops (Crustacea; Copepoda) from subterranean habitats in southern Indiana, USA.- Jeffersoniana, 12, 1-65, Martinsville.

Reid, J. W., 2006: Local recreation parks as hospitable habitats for small aquatic animals: examples of copepod crustaceans in Virginia.- Banisteria, 27, 10 15, Richmond.

Reid, J. W., In review: Two new species of Itocyclops, and a new record of I. yezoensis (Copepoda: Cyclopoida: Cyclopidae) from the eastern U.S.A.- Journal of Crustacean Biology, Lawrence.

Reid, J. W. \& Strayer, D. L., 1994: Diacyclops dimorphus, a new species of copepod from Florida, with comments on morphology of interstitial cyclopine cyclopoids.- Journal of the North American Benthological Society, 13: 250-265, Lawrence.

Reid, J. W., Strayer, D. L., McArthur, J. V., Stibbe, S. E. \& Lewis, J. J., 1999: Rheocyclops, a new genus of copepods form the southeastern and central U.S.A. (Copepoda: Cyclopoida: Cyclopidae).- Journal of Crustacean Biology, 19, 384-396, Lawrence.
Reid, J. W. \& Ishida, T., 2000: Itocyclops, a new genus proposed for Speocyclops yezoensis (Copepoda: Cyclopoida: Cyclopidae).- Journal of Crustacean Biology, 20, 589-596, Lawrence.

Robertson, A. L. \& Milner, A. M., 2006: The influence of stream age and environmental variables in structuring meiofaunal assemblages in recently deglaciated streams.-Limnology and Oceanography, 51, 14541465, Lawrence.

Strayer, D. L. \& Reid, J. W., 1999: Distribution of hyporheic cyclopoids (Crustacea: Copepoda) in the eastern United States.- Archiv für Hydrobiologie, 145, 79-92, Stuttgart.

Yeatman, H. C., 1964: A new cavernicolous cyclopoid copepod from Tennessee and Illinois.- Journal of the Tennessee Academy of Science, 39, 95-98, Murfreesboro.

Appendix 1. Most of the following records of copepods from groundwater habitats in and near the Interior Low Plateaus are taken from the unpublished reports of Lewis, and Lewis et al. (1996-2006). Records from Kofoid (1899), Chappuis (1929, 1931), Yeatman (1964), Barr (1967), Bunting (1973), Strayer \& Reid (1999), and Reid (2004) have also been included.

\section{ORDER COPEPODA \\ SUBORDER CYCLOPOIDA \\ FAMILY CYCLOPIDAE}

Acanthocyclops brevispinosus (Herrick, 1884)

ILLINOIS: Monroe Co.: Camp Vandeventer Spring.

Acanthocyclops einslei Mirabdullayev \& Defaye, 2004 ILLINOIS: Monroe Co.: Bat Sump Cave; INDIANA: Greene Co.: Rankin Spring.

Acanthocyclops exilis (Coker, 1934)

KENTUCKY: Edmonson Co.: Mammoth Cave (Barr 1967).

Acanthocyclops parasensitivus Reid, 1998

INDIANA: Clark Co.: Seep spring, Burns Hollow; TENNESSEE: Grundy Co.: Big Mouth Cave; KENTUCKY: Pulaski Co.: Buck Creek, sandbar (Strayer \& Reid 1999).

Acanthocyclops robustus (G.O. Sars, 1863)

ILLINOIS: Monroe Co.: Bat Sump Cave; INDIANA: Harrison Co.: Baker Hollow Cave, Black Medusa Cave, Bussabarger's Cave, Harrison Cave Spring, 
Harrison Spring, Stygian River Cave, Wallier Cave; Jefferson Co.: well, Grapevine Branch section 19, Big Oaks National Wildlife Refuge (BONWR); Lawrence Co.: Buddha Cave, Burton Hollow Cave, Henshaw Bend Cave; Orange Co.: Wesley Chapel Gulf Cave; Washington Co.: Endless Cave; KENTUCKY: Edmonson Co.: Mammoth Cave (Chappuis 1931); TENNESSEE: White Co.: Lost Creek Cave.

Acanthocyclops venustoides (Coker, 1934)

INDIANA: Crawford Co.: well at abandoned house on road to Mesmore Cliffs area; Harrison Co., Bussabarger's Cave; Jefferson Co.: well, NE quarter-section 7, Big Creek drainage, BONWR; White Co.: Field drain tile outlet, $5.3 \mathrm{~km}$ west of Brookston; ILLINOIS: Vermilion Co.: drain tile outlet near Jordan Creek (Yeatman 1964).

Acanthocyclops vernalis (Fischer, 1853)

INDIANA: Clark Co.: Seep spring on stream bank, Burns Hollow; ILLINOIS: Monroe Co.: Bat Sump Cave; KENTUCKY: Edmonson Co.: Mammoth Cave (Chappuis 1931); TENNESSEE: Grundy Co.: Bigmouth Cave (Yeatman 1964); Rhea Co.: Marler Cave; Rutherford Co.: Patton Cave, pool; Jackson Co.: Haile Cave, rimstone pools; ILLINOIS: Vermilion Co.: drain tile outlet near Jordan Creek (Yeatman 1964).

Diacyclops bicuspidatus (Claus, 1857)

KENTUCKY: Edmonson Co.: Mammoth Cave (Kofoid 1899). This record may refer to D. thomasi (S. A. Forbes, 1882), which was long considered a subspecies of D. bicuspidatus, and was frequently confused with the former in the earlier North American literature. Both D. bicuspidatus and D. thomasi are widespread in North America; D. thomasi is much more common, especially in the plankton of lakes and ponds, and also occurs in smaller waterbodies such as rock pools. This record is not treated further herein.

Diacyclops chrisae Reid, 1992

INDIANA: White Co.: Field drain tile outlet, $5.3 \mathrm{~km}$ west of Brookston.

Diacyclops conversus Reid, 2004

INDIANA: Crawford Co.: Bou-Rouch pumpwell on Blue River.

Diacyclops crassicaudis brachycercus Kiefer, 1927 INDIANA: Harrison Co.: Hiser Spring Cave.
Diacyclops jeanneli Chappuis, 1929

INDIANA: Clark Co.: Seep spring in Burns Hollow; Crawford Co.: Marengo Cave; Floyd Co.: well, New Albany near Indiana University Southeast; Harrison Co.: Devils Graveyard Cave; Orange Co.: Apple Cave, Murray Spring Cave, Tucker Lake Spring Cave; Washington Co.: Fredericksburg Cave.

Diacyclops indianensis Reid, 2004

INDIANA: Jefferson Co.: Henry Dilk Falls Cave; TENNESSEE: Fentress Co.: Redbud Cave; Franklin Co.: Crownover Saltpeter Cave, Keith Cave, Little Crow Creek Cave; Grundy Co.: Big Mouth Cave, Dry Cave; Pickett Co.: Bunkum Cave.

Diacyclops lewisi Reid, 2004

INDIANA: Jefferson Co.: well in Big Creek drainage section 7, BONWR: Jennings Co.: well in Graham Creek drainage section 18, BONWR.

Diacyclops navus (Herrick, 1882)

INDIANA: Floyd Co.: abandoned cistern near intersection of I-265 and Grant Line Road; Gibson Co.: well $5.6 \mathrm{~km}$ east of Fort Branch.

Diacyclops nearcticus Kiefer, 1934

INDIANA: Crawford Co.: Bou-Rouch pumpwell on Blue River; Orange Co.: Bond Cave; KENTUCKY: Pulaski Co.: Stab Cave; TENNESSEE: White Co.: Lost Creek Cave; DeKalb Co.: Smith Fork, gravel bar (Strayer \& Reid 1999).

Diacyclops salisae Reid, 2004

INDIANA: Jennings Co.: well, Otter Creek drainage, section 31, BONWR.

Diacyclops sororum Reid, 1992

INDIANA: Crawford Co.: Bou-Rouch pumpwell on Blue River; Harrison Co.: Squire Boone Caverns; KENTUCKY: Pulaski Co.: Buck Creek, sandbar (Strayer \& Reid 1999).

Diacyclops yeatmani Reid, 1988

INDIANA: Crawford Co.: Bou-Rouch pumpwell on Blue River; TENNESSEE: Grundy Co.: Big Mouth Cave (Yeatman 1964, as Cyclops clandestinus); Van Buren Co.: Camps Gulf Cave, Swamp River Cave; ILLINOIS: Vermilion Co.: drain tile outlet near Jordan Creek (Yeatman 1964).

Diacyclops undescribed species KENTUCKY: Pulaski Co.: Blowing Cave. 
Eucyclops agilis (Koch, 1838)

ILLINOIS: Monroe Co.: Haney Spring; INDIANA: Greene Co.: Rankin Spring; Orange Co.: Rise of Lost River at Orangeville; KENTUCKY: Edmonson Co.: Mammoth Cave [Kofoid 1899, Chappuis 1931 (as E. serrulatus), Barr 1967]; Pulaski Co.: Buck Creek, sandbar (Strayer \& Reid 1999); TENNESSEE: Grundy Co.: Bigmouth Cave (Yeatman 1964); DeKalb Co.: Smith Fork, gravel bar (Strayer \& Reid 1999); Rutherford Co.: Herring Cave.

Eucyclops conrowae Reid, 1992

INDIANA: Harrison Co.: Firetail Spring; Orange Co.: Rise of Lost River at Orangeville.

Eucyclops elegans (Herrick, 1884)

INDIANA: Crawford Co.: Marengo Cave; Greene Co.: Rankin Spring; Monroe Co.: Harp Spring Cave; Orange Co.: Rise of Lost River at Orangeville; KENTUCKY: Edmonson Co.: Mammoth Cave (Chappuis 1931); TENNESSEE: White Co.: Lost Creek Cave.

Itocyclops undescribed species

KENTUCKY: Pulaski Co.: Sheep Cave South, rimstone pool; Stab Cave, rimstone pool; Redbud Cave, rimstone pool; TENNESSEE: Jackson Co.: Dud Cave, shallow drip pool.

Macrocyclops albidus (Jurine, 1820)

ILLINOIS: Monroe Co.: Bat Sump Cave; INDIANA: Greene Co.: Ashcraft Cave; Lawrence Co.: Buddha Cave; Monroe Co.: Well Cave; Orange Co.: Rise of Lost River at Orangeville; KENTUCKY: Edmonson Co.: Mammoth Cave (Kofoid 1899); TENNESSEE: Rutherford Co.: Herring Cave, pool; Patton Cave, pool.

Macrocyclops fuscus (Jurine, 1820)

INDIANA: Greene Co.: Rankin Spring; Harrison Co.: Stygian River Cave; KENTUCKY: Edmonson Co.: Mammoth Cave (Chappuis 1931, Barr 1967).

Megacyclops donnaldsoni (Chappuis, 1929)

INDIANA: Crawford Co.: Hidden Spring Cave, Wildcat Cave; Lawrence Co.: Donnaldson Cave (Chappuis 1931); KENTUCKY: Edmonson Co.: Mammoth Cave, Roaring River (Barr 1967); TENNESSEE: Grundy Co.: Dry Cave; McMinn Co.: unnamed cave (Bunting 1973).
Megacyclops latipes (Lowndes, 1927)

INDIANA: Harrison Co.: Rands Spring; Monroe Co.: Well Cave; TENNESSEE: Grundy Co.: Big Mouth Cave, Trussell Cave; Rhea Co.: Marler Cave.

Megacyclops undescribed species

INDIANA: Martin Co.: Bluff House Cave; Orange Co.: Campground Cave.

Mesocyclops edax (S.A. Forbes, 1891) ILLINOIS: Monroe Co.: Camp Vandeventer Spring, Camp Vandeventer Cave; INDIANA: Crawford Co.: Hidden Spring Cave; KENTUCKY: Edmonson Co.: Mammoth Cave (Chappuis 1931; Barr 1967).

Microcyclops rubellus (Lilljeborg, 1901)

ILLINOIS: St. Clair Co.: Stemler Cave; INDIANA: Crawford Co.: Bou-Rouch pumpwell on Blue River; KENTUCKY: Pulaski Co.: Buck Creek, sandbar (Strayer \& Reid 1999); TENNESSEE: DeKalb Co.: Smith Fork, gravel bar (Strayer \& Reid 1999).

Orthocyclops modestus (Herrick, 1883)

ILLINOIS: Monroe Co.: Bat Sump Cave; INDIANA: Crawford Co.: well at abandoned house near Mesmore Cliffs; Harrison Co.: Binkley Cave; Jefferson Co.: well, Grapevine Branch section 19, BONWR; TENNESSEE: Rutherford Co.: Patton Cave, pool; Grundy Co.: Bigmouth Cave (Bunting 1973).

Paracyclops canadensis (Willey, 1934)

INDIANA: Crawford Co.: Carnes Mill Spring Cave.

Paracyclops chiltoni (Thomson, 1882)

INDIANA: Harrison Co.: Binkley Cave, Rands Spring; Lawrence Co.: Henshaw Bend Cave; Washington Co.: Mill Cave; KENTUCKY: Edmonson Co.: Mammoth Cave [Chappuis, 1931, reported P. finitimus Kiefer, 1929, but Chappuis' record was interpreted by Barr, 1967 as P. fimbriatus (Fischer, 1853). Paracyclops finitimus is currently considered a junior subjective synonym of $P$. chiltoni, and $P$. fimbriatus is not thought to occur in the Americas; see Karaytug \& Boxshall 1998]; Pulaski Co: Buck Creek, sandbar (Strayer \& Reid 1999).

Rheocyclops indiana Reid, 1999

INDIANA: Orange Co.: Elrod Cave; Washington Co.: Ladder Cave.

Rheocyclops undescribed species ALABAMA: Jackson Co.: Russell Cave (Russell Cave National Monument). 
Tropocyclops extensus Kiefer, 1931

INDIANA: Harrison Co.: Bussabargers Cave, Squire Boone Caverns.

Tropocyclops prasinus (Fischer, 1860)

KENTUCKY: Edmonson Co.: Mammoth Cave (Chappuis 1931). Chappuis' record of T. prasinus may refer to the subspecies mexicanus later described by Kiefer.

Tropocyclops prasinus mexicanus Kiefer, 1938

ILLINOIS: Monroe Co.: Camp Vandeventer Spring, Camp Vandeventer Cave; INDIANA: Washington Co.: Endless Cavern; KENTUCKY: Edmonson Co.: Mammoth Cave (Barr 1967).

\section{SUBORDER HARPACTICOIDA FAMILY CANTHOCAMPTIDAE}

Attheyella (Neomrazekiella) illinoisensis (S. A. Forbes, 1882)

INDIANA: Crawford Co.: Megenity Peccary Cave; Monroe Co.: May Cave.

Attheyella (Neomrazekiella) nordenskioldii (Lilljeborg, 1902)

ILLINOIS: Monroe Co.: Haney Spring, Metter Cave; INDIANA: Clark Co.: seep spring in Burns Hollow; Crawford Co.: Wymans Cave; Harrison Co.: Rands Spring; Jefferson Co.: well, NW quarter-section 18, Graham Creek drainage BONWR; Monroe Co.: Shirley Springs, Waterfall Cave; Washington Co.: Karens Pit Cave; Orange Co.: Garlow Spring Cave.

Attheyella (Ryloviella) pilosa Chappuis, 1929

INDIANA: Clark Co.: seep spring in Burns Hollow; Crawford Co.: Wymans Cave; Harrison Co.: Squire Boone Caverns; Monroe Co.: Waterfall Cave; Washington Co.: Baynes Spring Cave, Endless Cavern, Nevin Spring Cave; KENTUCKY: Edmonson Co.: Mammoth Cave (Chappuis 1931).
Bryocamptus (Bryocamptus) newyorkensis (Chappuis, 1927)

TENNESSEE: Jackson Co.: Dud Cave, shallow drip pool.

Bryocamptus (Limocamptus) morrisoni morrisoni (Chappuis, 1929)

INDIANA: Lawrence Co.: Donnaldson Cave (Chappuis 1929, 1931).

Bryocamptus (Limocamptus) morrisoni elegans (Chappuis, 1929)

KENTUCKY: Hart Co.: Horse (Hidden River) Cave (Chappuis 1929, 1931).

Bryocamptus (Limocamptus) nivalis (Willey, 1925) INDIANA: Harrison Co.: Harrison Cave Spring.

Bryocamptus (Limocamptus) undescribed species TENNESSEE: Overton Co.: Mill Hollow Cave.

Moraria cristata Chappuis, 1929

INDIANA: Lawrence Co.: Donnaldson Cave (Chappuis 1931).

\section{SUBORDER CALANOIDA \\ FAMILY CENTROPAGIDAE}

Osphranticum labronectum S. A. Forbes, 1882

TENNESSEE: Rutherford Co.: Patton Cave, pool.

\section{FAMILY DIAPTOMIDAE}

Skistodiaptomus pallidus (Herrick, 1879)

INDIANA: Harrison Co.: Harrison Cave Spring, Stygian River Cave; KENTUCKY: Edmonson Co.: Mammoth Cave (Barr 1967) 
